\title{
Implementasi Prinsip-Prinsip Good Governance dalam Memajukan Kabupaten Jember
}

\author{
Moh Anwar Nuris ${ }^{1}$ \\ 1Fakultas Syariah, IAIN Jember. E-mail: anwarnuriez69@gmail.com
}

\begin{tabular}{|c|c|}
\hline Article & Abstract \\
\hline $\begin{array}{l}\text { How to cite: } \\
\text { Moh Anwar Nuris, } \\
\text { 'Implementasi Prinsip- } \\
\text { Prinsip Good Governance } \\
\text { dalam Memajukan } \\
\text { Kabupaten Jember' (2020) } \\
\text { Vol. } 1 \text { No. } 3 \\
\text { Rechtenstudent Journal } \\
\text { Fakultas Syariah IAIN } \\
\text { Jember. } \\
\text { Histori artikel: } \\
\text { Submit } 1 \text { September 2020; } \\
\text { Diterima } 15 \text { November } \\
\text { 2020; Diterbitkan } 7 \\
\text { Desember 2020. } \\
\text { ISSN: } \\
\text { 2723-0406 (media cetak) }\end{array}$ & $\begin{array}{l}\text { Abstrak } \\
\text { Implementasi good governance sebagai landasan nilai penyelenggaraan } \\
\text { pemerintahan, yang berorientasi pada pengembalian harga diri rakyat demi } \\
\text { membangun kembali citra pemerintahan sebagai pelayan yang adil. Hal ini di } \\
\text { tambah dengan semakin kuatnya tuntutan demokrasi pengakuan akan hak-hak } \\
\text { asasi manusia yang melahirkan tuntutan terhadap manajemen yang bercirikan } \\
\text { pemerintahan yang baik (good governance). Hasil penelitian menunjukkan bahwa: (1) } \\
\text { implementasi prinsip-prinsip good governance yang ada di Pemerintahan Kabupaten } \\
\text { Jember masih kurang karena banyak pelanggaran yang dilakukan oleh pihak } \\
\text { pemerintah (2) proses Pelaksanaan Prinsip-prinsip good governance dalam } \\
\text { memajukan Kabupaten Jember, masih kurang karena banyaknya pelanggaran yang } \\
\text { dilakukan oleh Pemerintah Kabupaten Jember dalam pelaksanaan dari dugaan } \\
\text { pelanggaran perundang-undangan. Mulai manajemen aparat sipil Negara (ASN), } \\
\text { penggunaan kewenangan pejabat administrasi Pemerintah, dan pengelolaan } \\
\text { keuangan daerah yang berakibat masif pada ASN serta kepada Masyarakat } \\
\text { sehingga yang berakibat kepada Pemakzulan Bupati Jember oleh pihak DPRD } \\
\text { Jember hal ini berpengaruh terhadap pelaksanaan Pemerintahan yang ada di } \\
\text { Kabupaten Jember sehingga berakibat terhadap kinerja Bupati Jember. (3). Faktor } \\
\text { yang menghambat penyusunan RAPBD dalam melaksanakan prinsip-prinsip good } \\
\text { governance dalam pemerintahan di Kabupaten Jember. } \\
\text { Kata Kunci: Good Governance, Pemerintahan, Kabupaten Jember. }\end{array}$ \\
\hline
\end{tabular}




\section{Pendahuluan}

Pasca runtuhnya kekuasaan pemerintahan orde baru, membawa perubahan baik dalam sandi pemerintahan maupun politik. Isu desentralisasi dalam demokrasi makin keras disuarakan. Hal ini kemudian berdampak pada pemerintahan (Legislatif dan Eksekutif) yang telah menghasilkan tiga produk perundang-undangan yang mengubah wajah sistem pemerintahan di Indonesia. ${ }^{1}$ Produk pertama adalah Undang-Undang Nomor 22 Tahun 1999 tentang Pemerintahan Daerah, yang telah diperbarui menjadi Undang-Undang Nomor 23 Tahun 2014, dengan fokus utama pada pemberian wewenang yang lebih besar kepada daerah Kabupaten dan Kota dalam mengelola pemerintahan dan pembangunan.

Implikasi dari Undang-Undang ini terhadap pembangunan daerah mempunyai kewenangan dalam menetapkan kebijakan dalam perencanaan dan pembangunan daerah. Melalui desentralisasi kebijakan daerah mempunyai kewenangan dalam menetapkan kebijakan dalam perencanaan dan pelaksanaan pembangunan daerah.

Sedangkan kewenangan Pemerintahan Pusat dalam pelaksanaan pembangunan hanya meliputi kebijakan tentang perencanaan pembangunan Nasional dan pengendalian pembangunan Nasional secara makro. Kedua, Undang-Undang Nomor 28 Tahun 1999, mengatur tentang Pelaksanaan Pemerintahan yang baik, yang telah diperbarui menjadi Undang-Undang Administrasi Pemerintahan Nomor 30 Tahun 2014 dengan fokus pada pelaksanaan Asas-asas Umum Pemerintahan Yang Baik (AUPB). Ketiga, Undang-Undang Nomor 33 Tahun 2004 tentang Pelaksanaan Perimbangan Keuangan Antara Pemerintahan Pusat dan Daerah, dengan fokus utama pada pengalokasian dana dan wewenang untuk mengelolanya yang lebih besar kepada Daerah Kabupaten/ Kota. Dengan ketiga UndangUndang ini menjadi landasan digunakannya konsep Good Governance sebagai landasan nilai penyelenggaraan pemerintah, yang berorientasi pada pengembalian harga diri rakyat demi membangun kembali citra pemerintahan sebagai pelayan yang adil. Hal ini ditambah dengan semakin kuatnya tuntutan demokrasi dan pengakuan akan hak-hak asasi manusia yang melahirkan tuntutan terhadap manajemen yang berkualitas, yang bercirikan pemerintahan yang baik (Good Governance).

Demokrasi² $^{2}$ sebagai suatu sistem pemerintahan yang berdasarkan kedaulatan rakyat. Sistem demokrasi Pancasila dalam pelaksanaan ketatanegaraan Republik Indonesia telah melembagakan diri dalam lembaga negara di Pusat sampai wujudnya yaitu:

a. Rakyat yang menentukan bentuk dan isi Pemerintahan yang dikehendakinya sesuai dengan hati nuraninya;

b. Pemerintahan harus memfokuskan perhatiannya kepada kepentingan rakyat dalam rangka tercapainya kemakmuran yang merata;

c. Segala langkah kebijakan pemerintah, haruslah berdasarkan atas hasil musyawarah;

d. Dalam mengambil keputusan harus sesuai dengan jiwa Pancasila;

e. Kestabilan pemerintah sebagai suatu syarat dapat terlaksananya program-program, haruslah tetap dapat menampung adanya perbedaan pendapat yang berkembang dalam masyarakat luas;

\footnotetext{
1 Deddy Supriady Bratakusumah, Dadang Solihin, Otonomi Penyelenggaraan Pemerintahan Daerah, (Jakarta : PT Gramedia Pustaka Utama, 2001), 2

${ }^{2}$ Ridwan HR. Hukum Administrasi Negara, (Jakarta : Rajawali Pers, 2008), 8
} 
f. Perbedaan pendapat itu wajar, asal dalam penyelesaiannya menurut aturan alam demokrasi dengan menaati bersama sistem kelembagaan dan musyawarah serta terus berpijak pada kepentingan rakyat sebagai keseluruhan.

Akan tetapi pemberian otonomi daerah tidak berarti permasalahan bangsa akan selesai dengan sendirinya. Otonomi daerah tersebut harus diikuti dengan serangkaian reformasi disektor publik. ${ }^{3}$ Dimensi sektor publik tersebut tidak saja sekedar perubahan format lembaga, akan tetapi mencakup perubahan alat-alat yang digunakan untuk mendukung berjalannya lembaga-lembaga tersebut secara ekonomis, efisien, efektif, transparan dan akuntabel sehingga cita-cita reformasi yaitu menciptakan good governance benar-benar tercapai.

Adapun faktor-faktor yang mempengaruhi penegakan hukum menurut Soerjono Soekarto ${ }^{4}$ antara lain:

1. Faktor hukumnya sendiri, yang akan dibatasi oleh Undang-Undang saja;

2. Faktor penegak hukumnya, yakni pihak-pihak yang membentuk dan menerapkan hukum;

3. Faktor sarana dan fasilitas, yang mendukung penegakan hukum;

4. Faktor masyarakatnya, yakni lingkungan di mana hukum tersebut berlaku dan diterapkan;

5. Faktor budaya, yakni sebagai hasil karya, cipta dan rasa yang didasarkan pada karsa manusia di dalam pergaulan hidup.

Kelima faktor yang dikemukakan Soekarto tersebut, tidaklah disebutkan faktor mana yang sangat dominan berpengaruh, semua faktor tersebut harus saling mendukung untuk membentuk efektivitas hukum.

Menurut Ari Dwipayana ${ }^{5}$ secara normatif desentralisasi bisa mendorong good governance, karena ia hendak mendekatkan diri ke masyarakat dan sekaligus meningkatkan partisipasi masyarakat dalam urusan lokal yang bakal mendorong transparansi, akuntabilitas, dan responsivitas pemerintah lokal.

UNDP mengajukan 9 karakteristik good governance ${ }^{6}$ sebagai berikut:

a. Partisipasi menuntut setiap warga negara mempunyai hak dan kewajiban untuk mengambil bagian dalam proses bernegara;

b. Penegakan hukum, salah satu syarat kehidupan demokrasi adalah adanya penegakan hukum yang dilaksanakan dengan adil dan tanpa pandang bulu;

c. Transparansi, adanya keterbukaan yang mencakup aspek aktivitas yang menyangkut kepentingan publik mulai dari proses pengambilan keputusan, penggunaan dana-dana publik sampai pada tahapan evaluasi;

d. Daya tangkap, yaitu proses yang dilakukan di setiap institusi harus diarahkan pada upaya untuk melayani berbagai pihak yang berkepentingan;

e. Berorientasi konsensus, yaitu bertindak sebagai mediator bagi berbagai kepentingan yang berbeda untuk mencapai kesepakatan;

f. Berkeadilan, yaitu memberikan kesempatan yang sama terhadap laki-laki maupun perempuan dalam upaya meningkatkan dan memelihara kualitas hidupnya;

\footnotetext{
${ }^{3}$ Haw. Widjaja, Otonomi Daerah dan Daerah Otonomi, (Jakarta : PT RajaGrafindo Persada. 2002), 109

${ }^{4}$ Daim A. Nurhayanto, Hukum Andministrasi, (Surabaya : Laskambang Justia, 2014), 8

${ }^{5}$ Ari Dwipayana, AAGN., Et,Al. Membangun Good Governance Di Desa, (IRE Press : Yogyakarta, 2003), 16

${ }^{6}$ Sirajuddin, Sukriano Didik, Dan Winardi. Hukum Pelayanan Publik (Berbasis Partisipasi Dan Keterbukaan Informasi), (Jakarta : Press, 2012), 39
} 
g. Efektifitas dan efisiensi, yaitu segala proses dan kelembagaan diarahkan untuk menghasilkan sesuatu yang benar-benar sesuai dengan kebutuhan melalui pemanfaatan yang sebaik-baiknya terhadap sumber yang ada;

h. Akuntabilitas, yaitu para pengambil keputusan harus bertanggung jawab kepada publik sesuai dengan jenis keputusan, baik internal maupun eksternal;

i. Visi strategis, yaitu para pemimpin dan masyarakat memiliki perfektif yang luas dan jangka panjang dalam penyelenggaraan Pemerintahan dan pembangunan manusia dengan memahami aspek-aspek historis, kultural, dan kompleksitas sosial yang mendasari perfektif mereka.

Yasin Syahrul Limpo ${ }^{7}$ menjelaskan bahwa. "Prinsip-prinsip good governance belum diterapkan sepenuhnya dalam pelaksanaan fungsi pengawasan di daerah, khususnya terhadap pelayanan publik. Disebabkan lemahnya dukungan subtansi produk hukum, partisipasi sosial, transparansi, akuntabilitas dalam penyelenggaraan pelayanan publik, kurangnya tanggung jawab penyelenggara Pemerintah Daerah, serta belum jelasnya mekanisme penerapan prinsip-prinsip tersebut".

Dalam Undang-Undang Pemerintahan daerah seperti yang tertuang di dalam pasal 1 angka 2 Undang-Undang Nomor 23 Tahun 2014 tentang Pemerintahan daerah (UU Pemda), penyelenggaraan urusan pemerintahan oleh Pemerintah Daerah dan Dewan Perwakilan Rakyat Daerah menurut asas otonomi dan tugas pembantuan dengan prinsip otonomi seluasluasnya.

Dalam sistem dan prinsip Negara Kesatuan Republik Indonesia sebagaimana dimaksud dalam Undang-Undang Dasar Negara Republik Indonesia Tahun 1945, Peraturan Pemerintah Nomer 21 Tahun 2004 tentang penyusunan Rencana Kerja Pemerintah dan Anggaran Kementerian Negara/Lembaga, Pemerintah Pusat dan Pemerintah Daerah wajib menyusun Rencana Kerja Pemerintahan (RKP) dan Rencana Kerja Pemerintah Daerah (RKPD) sebagai pelaksana Rencana Pembangunan Jangka Menengah (RPJM). Kedua peraturan tersebut mengamanatkan bahwa perencanaan pembangunan daerah dilakukan berdasarkan peran dan kewenangan masing-masing stakeholders guna mewujudkan integritas, sinkronisasi, dan sinergitas pembangunan, antar pemangku kepentingan. ${ }^{8}$

Dalam pelaksanaannya, keterlibatan lembaga yang diamanatkan oleh Undang-Undang sangatlah menentukan karena akan terciptanya suatu tatanan yang lebih baik. Maka perlu adanya kerjasama atau koordinasi membuat suatu pemerintahan akan berjalan dengan baik sesuai dengan prinsip-prinsip good governance.

Namun dalam Rancangan Anggaran Pendapatan dan Belanja Daerah (RAPBD) ini sedikit menemui kendala dalam hal persetujuannya sehingga terjadi penundaan dalam penyusunan tersebut. Dengan melalui prinsip-prinsip good governance proses pembangunan yang dilakukan oleh Pemerintah diharapkan terciptanya suatu prinsip akuntabilitas, transparansi dan supremasi hukum dalam proses memajukan Kota di Kabupaten Jember.

Sehingga penelitian ini, penulis mengangkat judul "Implementasi Prinsip-Prinsip Good Governance Dalam Memajukan Kabupaten Jember" untuk memenuhi cita-cita reformasi tersebut, good governance tidak hanya harus diterapkan di Pemerintahan pusat saja tetapi di

\footnotetext{
${ }^{7}$ Limpo Yasin Syahrul, "Jurnal Ilmu Hukum ammana gappa" Vol 15 No 2, (Makassar : Fakultas Hukum Universitas Hasanuddun), 131

${ }_{8}$ Masjudin Ashari,Wahyunadi, Dan Hailuddin, "Jurnal Ekonomi Dan Kebijakan Publik" Vol. 6, No. 2, (Mataram : Fakultas Ekonomi, Universitas Mataram), 163
} 
setiap sendi-sendi pemerintahan mulai dari Kota, Kabupaten dan jajaran instansinya. Karena Pemerintahan Daerah memiliki peran penting dalam memajukan fungi pelayanan publik.

\section{Rumusan Masalah}

Perumusan masalah dalam penelitian kualitatif disebut dengan istilah fokus permasalahan. Bagian ini mencantumkan semua fokus permasalahan yang akan dicari jawabannya melalui proses penelitian. Fokus penelitian harus disusun secara singkat, jelas, tegas, spesifik, operasional yang dituangkan dalam bentuk kalimat tanya. ${ }^{9}$

1. Bagaimana konsep prinsip-prinsip good governance dalam pemerintahan di Kabupaten Jember?

2. Bagaimana pelaksanaan prinsip-prinsip good governance dalam pemerintahan di Kabupaten Jember?

3. Apa saja faktor-faktor yang menghambat penyusunan RAPBD dalam melaksanakan prinsip-prinsip good governance dalam pemerintahan di Kabupaten Jember?

\section{Metode Penelitian}

Metode penelitian menjelaskan semua langkah yang dikerjakan peneliti dari awal hingga akhir. ${ }^{10}$ Motode penelitian adalah cara yang digunakan peneliti untuk mendapatkan data dari informasi mengenai berbagai hal yang berkaitan dengan masalah yang diteliti. ${ }^{11}$ Metode penelitian ini pada dasarnya merupakan cara ilmiah untuk mendapatkan data dengan tujuan kegunaan tertentu. Cara ilmiah berarti kegiatan penelitian ini didasarkan pada ciri-ciri keilmuan, yaitu rasional, empiris, dan sistematis.

Metode penelitian adalah metode yang digunakan dalam aktivitas penelitian misalnya mahasiswa yang melakukan penelitian untuk menyusun skripsi, disertasi, dan tesis. ${ }^{12}$ Sehingga penelitian ini menggunakan pendekatan normatif empiris. Pendekatan dan Jenis penelitian, dimana Jenis penelitian ini adalah penelitian deskriptif dengan pendekatan kualitatif yaitu penelitian yang bertujuan untuk memberikan gambaran mengenai fakta-fakta di lapangan yang berkaitan dengan objek penelitian. Penelitian ini bersifat normatif empiris yang selalu menitikberatkan pada sumber data sekunder.

Sedangkan dasar penelitian dilakukan dengan mengumpulkan data secara langsung di lapangan (field research). Lokasi Penelitian di dalam pelaksanaan penelitian ini, peneliti mengambil lokasi penelitian di wilayah Kabupaten Jember, yang dimana apakah sudah tertanam prinsip-prinsip good governance di tatanan Pemerintahan, Kantor DPRD Jember dan Masyarakat. Subjek penelitian sebagai sumber informasi dalam penelitian ini, peneliti menggunakan teknik purposive sampling atau penentuan informal ditentukan sendiri oleh peneliti dengan pertimbangan tertentu, pertimbangan tersebut misalnya, orang yang dianggap paling mengetahui tentang permasalahan yang akan diteliti.

Teknik Pengumpulan Data Peneliti menggunakan beberapa teknik dalam proses pengumpulan data, seperti wawancara, observasi dan dokumentasi yang masing-masing proses tersebut mempunyai peranan penting dalam upaya mendapatkan informasi yang akurat. Analisis data penelitian ini dilakukan kesimpulan dengan menggunakan analisis

\footnotetext{
9 Tim Penyusun, Pedoman Karya Ilmiah IAIN Jember, (Jember : IAIN Jember Press, 2018), 44

10 Tim penyusun, pedoman penulisan karya ilmiah IAIN jember (Jember : IAIN Jember press, 2018), 46

${ }^{11}$ Deni darmawan, metode penelitian kualitatif (Bandung PT. Rosdakarya, 2014), 127

12 Beni ahmad soebani, Metode Penelitian Hukum (Bandung CV Pustaka Setia, 2008), 11.
} 
kualitatif, yaitu data sekunder yang berupa teori, definisi dan substansinya dari beberapa literatur dan peraturan perundang-undangan serta data primer yang diperoleh dari wawancara dianalisis dengan teori dan pendapat para pakar yang relevan sehingga didapat kesimpulan tentang penerapan prinsip-prinsip good governance di Kabupaten Jember.

Keabsahan data setelah data terkumpul dan sebelum peneliti menulis laporan hasil penelitian, maka peneliti mengecek kembali data-data yang diperoleh dengan meng-cross check data yang telah didapat dari hasil observasi dan wawancara, dengan data yang didapat dari peneliti dapat di uji keabsahannya dan dapat dipertanggung jawabkan. Dalam penelitian ini, peneliti menggunakan teknik triangulasi. ${ }^{13}$

\section{Hasil dan Pembahasan}

\section{Konsep Prinsip-Prinsip Good Governance dalam Pemerintahan di Kabupaten Jember}

Dalam penerapannya, Pemerintah Kabupaten Jember berpegang dalam konsep prinsipprinsip good governance. Di mana mereka berpatokan kepada Peraturan Perundang-Undangan Dan Peraturan Kemendagri dalam mewujudkan Pemerintahan yang baik. Sehingga peraturan tersebut sebagai acuan dalam penerapan prinsip-prinsip good governance dalam penyusunan anggaran dalam pembangunan di Kabupaten Jember.

Namun ada permasalahan dalam penyelenggaraannya meskipun berpegang teguh kepada peraturan dalam realita di lapangan tidak sesuai. Dalam hal ini banyak media massa yang menulis tentang dugaan pelanggaran bupati, di mana dalam hal ini pemerintahan di Kabupaten Jember mendapatkan teguran dari Kementerian dalam Negeri terkait Mutasi yang dilakukan oleh Bupati Jember yang diduga tidak sesuai dengan Undang-Undang Nomor 5 Tahun 2015 tentang ASN, dan tidak dipatuhinya rekomendasi Komisi ASN (KASN). ${ }^{14}$

\section{Pelaksanaan Prinsip-Prinsip Good Governance dalam Pemerintahan di Kabupaten Jember}

Dalam pelaksanaan pemerintahan di Kabupaten Jember dimana pelaksanaannya masih kurang, meskipun dari sisi Hak Asasi Manusia Kabupaten Jember sangat baik dan antusias namun dalam sisi pembangunan dan administrasi sangat kurang. Hal ini yang membuat pemerintahan kabupaten Jember tidak berjalan dengan baik. Sehingga banyak permasalahan disana, dari dugaan pelanggaran perundang-undangan. Mulai manajemen Aparatur Sipil Negara (ASN), penggunaan kewenangan pejabat administrasi pemerintah, dan pengelolaan keuangan daerah yang berakibat masif pada ASN serta kepada Masyarakat.

Selain itu, adanya Peraturan Bupati Jember Tentang Kedudukan, Susunan, Organisasi, Tugas Dan Fungsi, Serta Tata Kerja (KSOTK) pada 3 Januari 2019, yang diduga melanggar Peraturan Pemerintah Nomor 18 Tahun 2016 Tentang Perangkat Daerah. "Termasuk dugaan pelanggaran terhadap surat dari Mendagri yang dilanjutkan oleh Gubernur Jatim. ${ }^{15}$ Bukan hanya itu saja baru-baru ini pihak DPRD Jember memutuskan dan melayangkan Pemakzulan Bupati Jember, dimana Pemakzulan tersebut berimbas kepada keberlangsungan politik Bupati

\footnotetext{
${ }^{13}$ Lexy J Molcong, Metode Penelitian Kualitatif (Bandung: Remaja Rosdakarya,2004),.178.

14 Radar Jember, 31 Desember 2019, 2.

15 Jatim.suara, 17 Desember 2019, 5.
} 
Jember dan pihak DPRD Jember akan mengajukannya kepada MA untuk mengabulkan hal tersebut. ${ }^{16}$

Hal ini lantas mempengaruhi terhadap kinerja pemerintahan yang ada di Kabupaten Jember sehingga berdampak kepada pembangunannya. Akibatnya, dampak tersebut ke masyarakat Jember dimana mereka tidak bisa merasakan pembangunan yang ada di Kabupaten Jember.

\section{Faktor yang Menghambat Penyusunan RAPBD dalam Melaksanakan Prinsip- Prinsip Good Governance dalam Pemerintahan di Kabupaten Jember}

Penundaan pembahasan anggaran yang di lakukan oleh DPRD Jember dengan pihak Bupati berkaitan dengan tidak adanya kuota CPNS dalam rekrutmen tahun ini untuk Jember. Namun belakangan terungkap persoalan-persoalan serius. Salah satunya adalah terbitnya surat teguran dari Mendagri. Sebagaimana diberitakan, DPRD Jember menunda pembahasan hingga pemerintah kabupaten melaksanakan perintah Menteri Dalam Negeri Tito Karnavian melalui Gubenur Jatim, Khofifah Indar Parawansa.

Tiga perintah yang harus dilaksanakan adalah pencabutan belasan surat keputusan mutasi, pencabutan 30 peraturan Bupati mengenai KSOTK (Kedudukan, Susunan Organisasi, Tugas dan Fungsi Serta Tata Kerja), dan tidak lanjut surat Menteri Dalam Negeri mengenai Peringatan atas pergantian Kepala Bidang Pengelolaan Informasi Administrasi Kependudukan Kabupaten Jember ${ }^{17}$. Hal ini menjadi salah satu pekerjaan rumah bagi pemerintah untuk memperbaiki sistem yang ada sesuai dengan prinsip-prinsip good governance sehingga tata kola dalam pembangunan untuk memajukan kota di Kabupaten Jember berjalan dengan baik.

\section{Kesimpulan}

Implementasi prinsip-prinsip good governance dalam memajukan Kabupaten Jember yang dimana berpatokan kepada peraturan perundang-undangan, namun dalam realita di lapangan tidak sesuai. Dalam hal ini banyak media massa yang menulis tentang dugaan pelanggaran bupati, dimana dalam hal ini pemerintahan di Kabupaten Jember mendapatkan teguran dari Kementerian Dalam Negeri terkait Mutasi yang dilakukan oleh Bupati Jember yang diduga tidak sesuai dengan Undang-Undang Nomor 5 Tahun 2015 tentang ASN, dan tidak dipatuhinya rekomendasi Komisi ASN (KASN).

Pelaksanaan Prinsip-prinsip good governance dalam memajukan Kabupaten Jember, masih kurang karena banyaknya pelanggaran yang dilakukan oleh Pemerintah Kabupaten Jember dalam pelaksanaan dari dugaan pelanggaran perundang-undangan. Mulai manajemen aparat sipil Negara (ASN), penggunaan kewenangan pejabat administrasi Pemerintah, dan pengelolaan keuangan daerah yang berakibat masif pada ASN serta kepada Masyarakat sehingga yang berakibat kepada Pemakzulan Bupati Jember oleh pihak DPRD Jember hal ini berpengaruh terhadap pelaksanaan Pemerintahan yang ada di Kabupaten Jember sehingga berakibat terhadap kinerja Bupati Jember.

\footnotetext{
${ }_{16}$ Portal Jember, 4 Agustus 2020, 1

${ }^{17}$ https://www.google.com/amp/s/jatim.suara.com/amp/read/2019/12/17/091613/puluhan anggota-dprdtandatangani-usulan-interpelasi-bupati-jember di akses 17-05-2020
} 
Faktor-faktor yang menghambat penyusunan RAPBD dalam melaksanakan prinsipprinsip good governance dalam pemerintahan di Kabupaten Jember, yaitu dari hasil penelitian langsung di lapangan yang telah dilakukan oleh peneliti ditemukan hasil bahwa masih terdapat beberapa hal yang dapat menghambat antara lain:

a. Kepemimpinan yang dijalankan oleh pihak Pemerintah di sini masih kurang maksimal karena banyak hambatan dan kendala terkait Pemerintahannya. Salah satu contoh pihak Pemerintah dan pihak DPRD Jember belum menemukan kata sepakat dalam pembahasan anggaran pembangunan pada tahun 2020 ini.

b. Komunikasi dan interaksi antara pihak pemangku jabatan sehingga mengakibatkan permasalahan dalam penyusunan RAPBD pada tahun 2020 tersebut tertunda. Hal ini seharusnya menjadi perhatian khusus untuk pemangku pemerintah antara Bupati dan DPRD untuk mementingkan nasib masyarakatnya karena apabila hal itu tertunda maka akan berdampak pada proses pembangunan yang ada di kabupaten Jember.

c. Sumber daya manusia yang terdapat dalam Pemerintah kurang menguasai bagaimana berorganisasi yang baik sehingga hal ini berdampak kepada pembangunan yang ada di Kabupaten.

\section{Daftar Pustaka}

\section{Buku}

A.Muh Ikhsan W R. "Implementasi Prinsip-Prinsip Good Governance Dalam Meningkatkan Kepuasan Pelayanan Publik Pada Kanto rUpt Dinas Pendapatan Provinsi Bali Di Kabupaten Badung." Skripsi, Universitas Hasanuddin, Makasar, 2017

Ashari Masjudin,Wahyunadi, Dan Hailuddin , 2015, "Jurnal Ekonomi Dan Kebijakan Publik" Vol. 6, No. 2, Mataram : Fakultas Ekonomi, Universitas Mataram.

Asshiddiqe Jimly, 2005. Format Kelembagaan Negara dan Pergeseran Kekuasaan Dalam UUD 1945. Yogyakarta: FH UII Press.

Beni ahmad soebani, 2008 Metode Penelitian Hukum. Bandung : CV Pustaka Setia.

Daim A. Nuryanto, 2014. Hukum Administrasi. Surabaya: Laskambang Justitia.

Darmawan Deni, 2014 metode penelitian kualitatif. Bandung : PT. Rosdakarya.

Dwipayana Ari, AAGN., et, al, 2003. Membangun Good Governanve di Desa. Yogyakarta: IRE Press.

Endang sukajati, Maria Magdalena dan Moh Mukeri warso, 2016, " jurnal of management" vol. 02, no. 02, Semarang : Fakultas Ekonomi Dan Bisnis, Universitas Pandanaran Semarang.

Futra Heriansyah. "Implementasi Good Governance Dalam Bidang Administrasi Desa Studi Kasus Dana Desa Jubung Kecamatan Sukorambi Kabupaten Jember." Skripsi, Universitas Muhammadiyah, Jember, 2016.

Haedar Akib, 2010, "jurnal administrasi publik" Vol 1 no 1, (Makasar : guru besar ilmu administrasi universitas negeri makassar.

I Made Artana. "Implementasi Prinsip-Prinsip Good Governance Dalam Meningkatkan Kepuasan Pelayanan Publik Pada Kantor Upt Dinas Pendapatan Provinsi Bali Di Kabupaten Badung." Skripsi, Universitas Warmadewa, Denpasar, 2014.

Kementerian Negara Perencanaan Pembangunan Nasional/Badan Perencanaan Pembangunan Nasional (Bappenas). Penerapan Tata Kepemerintahan yang Baik, Jakarta : Sekretariat Tim Pengembangan Kebijakan Nasional, 2007. 
Lexy J Molcong, 2004 Metode Penelitian Kualitatif, Bandung : Remaja Rosdakarya.

Limpo Yasin Syahrul, 2007, Jurnal Ilmu Hukum ammana gappa vol 15 Nomor 2. Makassar :

Fakultas Hukum Universitas Hasanuddin.

Peraturan Pemerintah Nomer 21 Tahun 2004 tentang penyusunan Rencana Kerja Pemerintah dan Anggaran Kementerian Negara/Lembaga.

Ridwan HR, 2016 Hukum Administrasi Negara, Jakarta : PT Raja Grafindo Persada.

Rosyada, Dede dkk, 2003. Demokrasi, HAM dan Masyarakat madani, Edisi revisi. Jakarta : Tim ICCE UIN Syarif Hidayatullah dan Prenada Media.

Sedarmayanti, 2004. Good Governance (Kepemerintahan yang Baik) Bagian kedua. Bandung: CV.Mandar Maju.

Sedarmayati, 2003. Good Govermance : Kepemerintahan Yang Baik Dalam Rangka Otonomi Daerah Upaya Membangun Organisasi Efektif dan Efisien Melalui Restrukturisasi dan Pemberdayaan. Bandung : Mandar Maju.

Sinambela, Lijan P. 2006. Reformasi Pelayanan Publik. Jakarta: Bumi Aksara.

Sirajuddin, Sukriano Didik, dan Winardi, 2012. Hukum Pelayanan Publik (Berbasis Pertisipasi dan Keterbukaan Informasi). Jakarta: Setara Press.

Sugiyono, 2003. Metode Penelitian Administrasi. Bandung: Alfabeta.

Supriady Deddy Bratakusumah, Dadang Solihin, 2001 Otonomi Penyelenggaraan Pemerintahan Daerah, Jakarta : PT Gramedia pustaka Utama.

Thoha Mifta, 2004. Birokrasi dan Politik di Indonesia. Jakarta: PT Raja Grafindo Persada.

Thoha, Miftah. 2003. Birokrasi dan Politik Indonesia. Jakarta : Raja Grafindo Persada.

Tim penyusun, pedoman, Penulisan karya ilmiah, IAIN Jember Press.

Usman Nurdin, Konteks Implementasi Berbasis Kurikulum, Bandung : CV Sinar Baru

Widjaja Haw, 2002 Otonomi Daerah Dan Daerah Otonom, Jakarta : PT RajaGrafindo Persada.

Widodo Joko, 2001. Good Governance : Telaah dari Dimensi Akuntabilitas dan Kontrol Birokrasi Pada Rra Desentralisasi dan Otonomi Daerah, Jakarta : PT Insan Cendekia.

\section{Perundang-undangan}

Undang-Undang No. 33 Tahun 2004 tentang perimbangan Keuangan Antara Pemerintah Daerah dan Pemerintah Pusat.

Undang-Undang Nomor 22 Tahun 1999 tentang Pemerintahan Daerah, yang telah di perbarui menjadi Undang-Undang Nomor 23 Tahun 2014.

Undang-Undang Nomor 23 Tahun 2014 tentang Pemerintahan daerah (UU Pemda) Pasal 1 ayat 2 .

Undang-Undang Nomor 28 Tahun 1999, mengatur tentang pelaksanaan Pemerintahan Yang Baik yang telah diperbarui menjadi Undang-Undang Administrasi Pemerintahan Nomor 30 Tahun.

Undang-Undang Nomor 33 Tahun 2004 tentang Pelaksanaan Perimbangan Keuangan Antara Pemerintah Pusat dan Daerah.

\section{Laman}

http://kbbi.web.id>implementasi diakses 20-08-2019

https://www.google.com/amp/s/jatim.suara.com/amp/read/2019/12/17/091613/puluhan anggota-dprd-tandatangani-usulan-interpelasi-bupati-jember di akses 17-05-2020 